\title{
Construction and validation of forms: systematization of the care of people under hemodialysis
}

\author{
Construção e validação de impressos: sistematização do cuidado de pessoas em hemodiálise \\ Construcción y validación de impresos: sistematización del cuidado de personas en hemodiálisis
}

\section{Cristina Arreguy-Sena', Tais de Oliveira Marques", Luciene Carnevale de Souza', Nathália Alvarenga-Martins', Paula Krempser ${ }^{\mathrm{III}}$, Luciene Muniz Braga ${ }^{\mathrm{IV}, \mathrm{V}}$, Pedro Miguel dos Santos Dinis Parreira ${ }^{\mathrm{VI}}$ \\ ' Universidade Federal de Juiz de Fora, Postgraduate Program in Nursing. Juiz de Fora, Minas Gerais, Brazil. \\ "Universidade Federal de Juiz de Fora, Faculty of Nursing, Undergraduate in Nursing. Juiz de Fora, Minas Gerais, Brazil. \\ I" Universidade do Estado do Rio de Janeiro, Faculty of Nursing, Postgraduate Program in Nursing. Rio de Janeiro, Brazil. \\ IV Universidade Federal de Viçosa, Department of Medicine and Nursing. Viçosa, Minas Gerais, Brazil. \\ ${ }^{v}$ Universidade de Lisboa, Doctoral Program in Nursing. Lisboa, Portugal. \\ ${ }^{V I}$ Escola Superior de Enfermagem de Coimbra, Research Unit in Health Sciences: Nursing. Coimbra, Portugal.}

How to cite this article:

Arreguy-Sena C, Marques TO, Souza LC, Alvarenga-Martins N, Krempser P, Braga LM, et al. Construction and validation of forms: systematization of the care of people under hemodialysis.

Rev Bras Enferm [Internet]. 2018;71(2):379-90. DOI: http://dx.doi.org/ 10.1590/0034-7167-2015-0130

Submission: 12-27-2015 Approval: 04-12-2017

\begin{abstract}
Objective: create and validate forms to subsidize the systematization of nursing care with people on hemodialysis. Method: institutional case study to support the systematization of assistance from the construction of forms for data collection, diagnoses, interventions and nursing results, using cross-mapping, Risner's reasoning, Neuman's theory, taxonomies of diagnoses, interventions and nursing results with application in clinical practice and validation by focal group with specialist nurses. Results: 18 people on hemodialysis and 7 nurses participated. Consensus content of form matter with specialist nurses in the area (Crombach 0.86). The papers captured 43 diagnoses, 26 interventions and 78 nursing results depicting human responses in their singularities. Final considerations: the validated forms fill a gap by enabling the capture of human responses from people on hemodialysis and by subsidizing the planning of nursing care on a scientific basis. Descriptors: Nursing Cares; Kidney Dialysis; Nursing Processes; Nursing Theory; Nursing.
\end{abstract}

\section{RESUMO}

Objetivo: criar e validar impressos para subsidiar a sistematização do cuidado de enfermagem com pessoas em hemodiálise. Método: estudo de caso institucional para subsidiar sistematização da assistência a partir da construção de impressos para coleta de dados, diagnósticos, intervenções e resultados de enfermagem, usando mapeamento cruzado, raciocínio de Risner, teoria de Neuman, taxonomias de diagnósticos, intervenções e resultados de enfermagem com aplicação na prática clínica e validação por grupo focal com enfermeiras especialistas. Resultados: participaram 18 pessoas em hemodiálise e 7 enfermeiros. Consensualizados conteúdos dos impressos com enfermeiras especialistas da área (Crombach 0,86). Os impressos captaram 43 diagnósticos, 26 intervenções e 78 resultados de enfermagem retratando respostas humanas em suas singularidades. Considerações finais: os impressos validados preenchem uma lacuna ao possibilitar a captação de respostas humanas de pessoas em hemodiálise e ao subsidiar o planejamento dos cuidados de enfermagem em bases científicas.

Descritores: Cuidados de Enfermagem; Diálise Renal; Processos de Enfermagem; Teoria de Enfermagem; Enfermagem.

\section{RESUMEN}

Objetivo: crear y validar impresos para subsidiar la sistematización del cuidado de enfermería con personas en hemodiálisis. Método: estudio de caso institucional para subsidiar la sistematización de la asistencia a partir de la construcción de impresos para recolección de datos, diagnósticos, intervenciones y resultados de enfermería, utilizando el mapeo cruzado, el raciocinio de Risner, la teoría de Neuman, taxonomías de diagnósticos, intervenciones y resultados de enfermería con aplicación en la práctica clínica y validación por grupo focal con enfermeras especialistas. Resultados: participaron 18 personas en hemodiálisis y 7 enfermeros. Consensuados 
contenidos de los impresos con enfermeras especialistas del área (Crombach 0,86). Los impresos captaron 43 diagnósticos, 26 intervenciones y 78 resultados de enfermería retratando respuestas humanas en sus singularidades. Consideraciones finales: los impresos validados llenan una brecha al posibilitar la captación de respuestas humanas de personas en hemodiálisis y al subsidiar la planificación de los cuidados de enfermería en bases científicas.

Descriptores: Cuidados de Enfermería; Diálisis Renal; Procesos de Enfermería; Teoría de Enfermería; Enfermería.

\section{INTRODUCTION}

It is estimated that the number of people with Chronic Kidney Disease (CKD) in hemodialysis treatment per year in Brazil is 100,397, with $90.1 \%$ performing conventional treatment. The prevalence is in the age group of 19 to 64 years $(66.9 \%)$ and in the male sex $(57.3 \%)^{(1)}$.

Hemodialysis is a complex procedure, performed in three shifts of four hours a week, through arteriovenous fistula (AVF) or double lumen venous catheter ${ }^{(2)}$, requiring daily adjustments and specific nursing care $\mathrm{e}^{(3-4)}$.

The insertion of the nurse in the process of caring for people undergoing hemodialysis needs to be based on theoretical, philosophical, conceptual and taxonomic references to capture the peculiarities of how people experience the process of renal replacement therapy and to plan with individualization care to the point of empowerment the nurses' work performance ${ }^{(4-5)}$.

The authors of this study, in the search to identify the diagnoses, interventions and nursing results that would characterize the profile of the people undergoing hemodialysis treatment, carried out a bibliographic survey that indicated information gaps and disconnection among nursing problems, interventions and results.

In order to capture the conflicts, social problems, acceptance of hemodialysis treatment by the people in renal replacement therapy, to direct the nurses' gaze to the human responses that portray the internally experienced stressors / situations, interpersonal and environmental relations, we opted to use the framework proposed by Betty Neuman ${ }^{(6)}$.

Neuman's theory conceives the human being as an open energy system whose stressful situations / circumstances can impact the health / disease process ${ }^{(6)}$. When applied in people under hemodialysis, this theory can favor the apprehension of ways of coping with changes in habits and routines; identification of imminent death; emergence of internal, interpersonal and environmental conflicts; and readjustment of the conceptions of life and of how they are assimilated, experienced and faced.

Such information is able to subsidize demands for care and therapeutical possibilities of nurses' performance, which will use professional knowledge and clinical practice to act on the variables (physiological, psychological, sociocultural, developmental and spiritual) that structure the human being in this conception ${ }^{(6)}$.

In view of the need to express what the most frequent diagnoses, interventions and nursing outcomes among hemodialysis patients were, we sought, in a language compatible with their sharing in different services, the taxonomic possibilities that could standardize the language of diagnoses, interventions and NAN$\mathrm{DA}^{(7)}$, Nursing Intervention Classification $(\mathrm{NIC})^{(8)}$ and Nursing Outcome Classification $(\mathrm{NOC})^{(9)}$, known as NNN, were selected.
According to NNN taxonomies, nursing diagnoses consist of: "clinical judgments of individual / family / community responses / experiences to health problems / actual or potential life processes ${ }^{\prime \prime(7)}$, which provide the basis for selecting the interventions, giving the nursing process the relational consistency necessary for the individualization of care. Nursing diagnoses can be of the following types: real, risk, health promotion and syndrome ${ }^{(7)}$.

Nursing interventions correspond to "any treatment based on judgment and clinical knowledge" ${ }^{\prime \prime(8)}$ and nursing outcomes are "states, behaviors or perceptions of individual, family or community"(9) measured by scales.

The assumptions of Neuman are: 1) the tension caused by environmental stressors leads the individual, in its total dimension, to interact with the environment (inter-relationship and interdependence); 2) the stimuli are interpreted by each individual in a differentiated way and 3) according to the individual's reaction it is possible to verify when the nursing should intervene $\mathrm{e}^{(5)}$. It is possible for nurses to infer in three levels of performance: a) primary - when it acts on the flexible line to minimize or prevent stress reaching the normal line of defense and generate misfits; b) secondary - when it strengthens the internal resistance lines to reduce the reaction; and c) tertiary - when it adapts and re-educates the individual to face stress situations, strengthening the resistance lines ${ }^{(6)}$.

Such research is justified by the following arguments: 1) the presence of gaps identified in the literature with the focus of taxonomies and the chosen theoretical framework; 2) the need for scientific work to support the clinical practices performed in the hemodialysis sectors; 3 ) assistance to nurses in complying with the legal recommendations recommended for their professional practice; and 4) subsidy for the nurse's role with people under hemodialysis to the point of empowering him to act in the context of the scientifically supported health team.

\section{OBJECTIVE}

In order to subsidize the nurse's role with people under hemodialysis, research was carried out with the objective of constructing and validating forms for recording the stages of the nursing process in this specialty.

\section{METHOD}

\section{Ethical aspects}

In this study, all ethical and legal research requirements involving humans were met. Research approved by Ethics Committee of $2 / 21 / 2013$. 


\section{Type of study}

Institutional case study with the construction of forms to systematize the nursing care in hemodialysis service.

\section{Methodological procedures- Study scenario}

The scenario was a hemodialysis service of the Unified Health System (SUS) of a city of Minas Gerais state, Brazil.

\section{Data source}

Sample of typicity composed of 18 people who were under hemodialysis during the period of data collection. Complete selection for nurses who cared and / or acted in the sector and had experience in the construction of theoretical-philosophical proposals for the category, totaling seven nurses.

The data were collected from February to May 2013 with subsequent analysis and re-adaptation of the forms.

All those who did not meet the inclusion criteria did not integrate the investigation, plus those under hemodialysis, who performed kidney transplantation, were hospitalized, died or requested to be discontinued in the investigation, and nurses who were on leave / leave during the collection period of data. Participants were individually recruited to conduct interviews, in which there were three denials of people under hemodialysis and total adherence of nursing professionals to participation in the focal group.

Hemodialysis patients were eligible: 1 ) they were attended in the morning or evening shifts; 2) age $\geq 18$ years and 3) presented diversity in the treatment / disease coping and were countersigned by the nurses to be treated in the hemodialysis sector for at least 12 months. Nurses specialized in nephrology, with renal replacement therapy in hemodialysis and clinical experience in the area or experience in the use of NNN taxonomies and theoretical models applicable to clinical practice were eligible.

\section{Data collection and organization}

Form papers were designed to record the history of nursing / evolution, diagnoses, interventions and nursing outcomes based on theoretical and philosophical references (Betty Neuman's theory) $)^{(6)}$; technical / conceptual / normative and methodological (class council resolutions) ${ }^{(10)}$; consensual thematic guidelines in the (inter) national literature; relational and communicational (normalization of records in records, interpersonal communication and therapeutic relationship); and taxonomic (NANDA I, NIC and NOC) ${ }^{(7-9)}$.

For the construction of the forms, the diagnostic reasoning was used from two techniques: cross-mappin (11) and Risner's reasoning $^{(12)}$.

Cross-sectional mapping ${ }^{(11)}$ sought to link nursing interventions, results and diagnoses, based on the available literature and / or the authors' experience with the themes (nursing classificatory systems and approach to people undergoing hemodialysis).

For this, the alignment of these taxonomies and the search for the correspondence between the domains and the classes of the taxonomies of intervention, result and nursing diagnosis were adopted as criterion. This strategy made it possible to fill the gap identified in the literature regarding the correspondence and articulation of the taxonomies for the desired theme.
With Risner's line of reasoning ${ }^{(12)}$ it was possible to apply the analytical and synthetic reasoning sequentially, considering the data collection (from observation, interaction and measurement), the scientific knowledge and experiences of nurses in search of the correspondence between these elements, and a standardized language adopted in the NANDA International taxonomy to link the structures that make up the nursing diagnoses.

The product obtained through the application of the two techniques by the researchers enabled the construction of prototypes of form material to support the collection of data, identification of problems (diagnoses), interventions and nursing results.

The prototype forms were applied to 18 participants who underwent hemodialysis, characterizing a period of period of data collection, analysis and treatment of the results obtained, based on clinical reasoning and nursing diagnosis.

The use of the snowball technique was a strategy adopted by nurses for the eligibility of potential hemodialysis patients, who were recruited by invitation to join the investigation through an interview, in which the prototype forms were applied. The eligibility criteria were the diversity of clinical situations and their human responses to hemodialysis treatment and renal disease.

Individual interviews were conducted with cursive records for the application of form material whose contents subsidized the identification of nursing diagnoses, interventions and results. By aligning this information it was possible to identify the taxonomic correspondences.

The contact with the people under hemodialysis was structured in theoretical foundations, communicational and semiological techniques in a sequence compatible with recommendations recommended in the nursing process $^{(10)}$.

There was consultation of the patient's report to support diagnostic decisions, and complement information regarding the defining characteristics or risk factors that were confirmatory for nursing diagnoses.

The content obtained with the application of the forms to the participants was grouped according to the affinity of how they faced the hemodialytic treatment and / or renal disease and motivated meetings to study cases using the focal group technique $^{(13)}$ with the participation of the nurses from the sector and researchers.

The focus group was operationalized from the presentation of four to five clinical cases per session, whose contents motivated the development of the technique under the coordination of a moderator and two secretaries (made cursive records of the suggestions, comments, additions and suppressions of contents).

It was the guiding questions that motivated the discussions in the focus group: 1) How long have you known $X$ in hemodialysis treatment? 2) What information do you mention that disclose your perception of it? How do people under hemodialysis behave in this service? 3) What information did you mention to us that were not known to you? 4) Are the nursing problems (diagnoses) listed by us consistent with the needs that you identify in the Mr. (s) X? 5) What therapeutic recommendations do you consider to be necessary and indispensable to be added to the planning of the nursing care of the Mr. (s) X? 6) Which indicators do they consider relevant 
for use as markers of quality of care and the achievement of therapeutic goals? 7) What do you nurses feel that you lacked in our approach when we mentioned the needs of Mr. (s) X? 8) What are your suggestions for improving our approach and making the form matter compatible for use in your clinical practice? 9) What are the points mentioned in this research that you, nurses, considered relevant? 10) Would you like to add some suggestion, recommendation, comment or information to what we talked about?

The content and dynamics of these meetings addressed the diagnoses, interventions and nursing outcomes constructed and planned specifically for the care needs of each previously interviewed hemodialysis person, besides expressing the interventions and the results of the therapeutic measures recommended by nurses in the nursing care planning.

The specialist nurses who participated in the focus group appreciated the content obtained, the level of comprehensiveness, the accuracy of the information and the adequacy of the planned therapeutic proposals until the consensus on the final version of the forms.

The use of the focus group made it possible to overcome the inability of some nurses who were unaware of the theoreticalphilosophical reference (Neuman theory) and the taxonomic system employed (NANDA I, NIC and NOC) and obtain from them the judgment of how much the contents captured with the prototypes of data collection, diagnoses, interventions and nursing results were able to portray reality and clinical situations / circumstances to the point of assessing the diversity of human responses of people under hemodialysis.

The definition of the components that integrate the nursing diagnoses (risk factors or defining characteristics) simultaneously guided the inclusion of approaches in the nursing history and created indications for the search for therapeutic interventions in the taxonomic system used that could be canceled, minimized or prevented. This strategy made it possible to ensure the alignment between the taxonomies used, aided by the similarity of some domains in which NIC and NOC taxonomies were structured ${ }^{(7-9)}$.

\section{Work steps}

The study was implemented in three stages: 1) construction of forms to support data collection, identification of diagnoses (NANDA I), interventions (NIC) and evaluation of nursing outcomes (NOC); 2) application of form matter in the clinical practice of nurses in the care of people under hemodialysis; and 3) presentation of the results of the application of the forms in the clinical practice of the specialist nurses with the focal group technique.

\section{Data analysis}

All the forms were applied to the participants in order to identify how much they could capture: 1) the diversity of emergent situations among the interviewees; 2) layout compatible with the storage of information in a smaller space, to ensure environmental sustainability for the records and possibility of transposition of the proposal prepared for a computerized electronic model; and 3) the nursing care process in a scientific way and structured in a theoretical/philosophical framework, using NNN taxonomies.

In this way, the forms were re-adapted so as to be able to capture the most common vulnerabilities among hemodialysis patients and to assist reflexive critical thinking in the diagnostic decision process in the clinical practice of hemodialysis nurses.

The focus group was performed with nurses to identify possible gaps in the approach and thus guided content inclusions to consensus.

\section{RESULTS}

Participating were 18 people who were under hemodialysis, 11 men, aged between 46 and 78 years, hemodialysis time from 12 months to 16 years; 6 patients underwent hemodialysis by double lumen catheter and 12 by AVF. Also participating were 7 nurses, all with less than 15 years of work in the area of nephrology and/or systematization of nursing care/use of theoretical models applied to nursing. The nurses knew in depth the family, social and economic context of the participants and provided care directly to them.

The nursing process ${ }^{(11)}$ (history, diagnosis, planning, implementation and evaluation of nursing) were portrayed in four forms: history, diagnoses, interventions and nursing results. They contemplated contents, conceptions and theoreticalphilosophical models ${ }^{(6)}$ pertinent to the theme.

The forms designed to carry out the systematization of nursing care were validated with a level of agreement among specialist nurses with scores $\geq 90 \%$ to fully adequate in terms of content, comprehensiveness and layout compatible with information storage and score $\geq 85 \%$ to be very adequate for the criteria of precision of the information and the adequacy of the planned therapeutic proposals. The reliability of the instruments was assessed by internal consistency (Cronbach's alpha values equal to 0.86 ).

It should be mentioned that the feasibility of the application of systematization in the context of nursing care to people undergoing hemodialysis was questioned, a fact attributed and justified by the distancing of a systematized care and the predominance of the technical profile present in the daily life of renal therapy services substitutive.

The first form was destined to the accomplishment of the history and evolution of nursing (Figure 1).

The Nursing History form (Figure 1) made it possible to identify: 24 situations involving intrapersonal stressors, 11 involving interpersonal stressors and 8 transpersonal stressors. This means that there was (dis) equilibrium in the continuum health/disease in two situations involving sociocultural variables; in three situations related to the physiological variables and in a situation linked to the psychological variable.

In a preliminary version, the layout of the vertical form was elaborated containing the proposed nursing theory, adopted to be used by the resident nurses and proved to be compatible with its use in electronic base, allowing modifications that would customize them for the situation of each participant in consultations and nursing process. 


\begin{tabular}{|c|c|c|c|c|}
\hline \multirow{2}{*}{\multicolumn{2}{|c|}{ Date: }} & \multicolumn{3}{|c|}{ NURSING HISTORY TO APPROACH PEOPLE UNDER HEMODIALYSIS } \\
\hline & & \multirow[t]{2}{*}{ Name: } & Date of birth: & Record: \\
\hline \multirow{2}{*}{\multicolumn{2}{|c|}{$(*)$}} & & Time under hemodialysis (HD): & Month/Year: \\
\hline & & Intrapersonal stressful factors & Interpersonal stressful factors & Transpersonal stressful factors \\
\hline \multirow{5}{*}{ 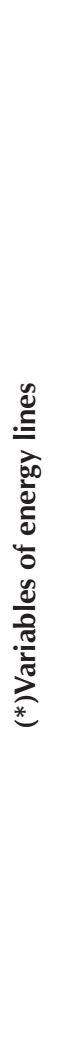 } & $\frac{T}{Q}$ & $\begin{array}{l}\text { Vital signs: }\left({ }^{*}\right) \mathrm{BP}, \mathrm{FC}, \mathrm{FR} \text {, pain; Ad- } \\
\text { ditional parameters: weight, swell- } \\
\text { ing; Exams: }\left({ }^{*}\right) \text { Ur, Cr, Na, K, Ca, P, } \\
\text { uric acid, hemogram, leucogram and } \\
\text { coaogulogram; Arteriovenous Fistula } \\
\text { Evaluation (AFE): permeability, bleed- } \\
\text { ing, integrity; Transplantation: indica- } \\
\text { tion; Nutrition: accession or not to food } \\
\text { restrictions; correlated comorbities. }\end{array}$ & $\begin{array}{l}\text { Degree of (in) dependence: type and } \\
\text { activity; } \\
\text { Mobility: autonomy, freedom; } \\
\text { Sexuality: sexual practice. }\end{array}$ & $\begin{array}{l}\text { Appearance and exposure of AFE: } \\
\text { discrimination, curiosity. }\end{array}$ \\
\hline & $\tilde{a}$ & $\begin{array}{l}\text { Feelings: positive, negative, of defense, } \\
\text { of coping; Strategies of coping: posi- } \\
\text { tive, negative, deffense mechanisms, } \\
\text { accession; Behaviors and attitudes: (in) } \\
\text { adequate; Self-image and self-concept: } \\
\text { perceptions and self-worth. }\end{array}$ & $\begin{array}{l}\text { Involvement/isolation: availability for } \\
\text { links. }\end{array}$ & $\begin{array}{l}\text { Profile of the person who has affin- } \\
\text { ity. }\end{array}$ \\
\hline & u & $\begin{array}{l}\text { Leisure, recreation and physical activi- } \\
\text { ties; life habits: autonomy, functional } \\
\text { capacity, activities of daily living (ADL) } \\
\text { and instrumental activities of daily living } \\
\text { (AIVD). }\end{array}$ & $\begin{array}{l}\text { Routine, habits and customs: type; } \\
\text { Conviviality with the other: friendship, } \\
\text { environments that attends; Links: affec- } \\
\text { tive life, significant people, family life; } \\
\text { Reference Person: availability. }\end{array}$ & $\begin{array}{l}\text { Social life: friendships, cultural activi- } \\
\text { ties; Habits and social life; } \\
\text { Transplantation: insertion in the } \\
\text { transplant queue, potential donor and } \\
\text { acceptance. }\end{array}$ \\
\hline & $\vec{n}$ & $\begin{array}{l}\text { Chronic kidney disease ethiology; Ad- } \\
\text { aptation to the disease; Treatment and } \\
\text { life style. }\end{array}$ & $\begin{array}{l}\text { Resilience: adjustment of hemodialysis to } \\
\text { weekly routine. }\end{array}$ & Use of social benefits. \\
\hline & $\overline{\bar{\omega}}$ & $\begin{array}{l}\text { Beliefs. } \\
\text { Celebrations. }\end{array}$ & $\begin{array}{l}\text { Transplantation: conception, expecta- } \\
\text { tion, Family donors. }\end{array}$ & $\begin{array}{l}\text { Rituals, Practices and Integration, } \\
\text { and feeling of belonging. }\end{array}$ \\
\hline
\end{tabular}

\begin{tabular}{|c|c|c|c|c|c|c|c|c|}
\hline \multirow[t]{3}{*}{ Date: } & \multicolumn{7}{|c|}{ Physiologic: Vital signs and measurement/evaluations } & \multirow{2}{*}{$\begin{array}{l}\text { (backside) } \\
\text { Record of emerging stressful factors }\end{array}$} \\
\hline & \multicolumn{2}{|c|}{ Weight } & \multicolumn{2}{|c|}{ Blood Pressure } & \multirow[t]{2}{*}{ Gained Volume } & \multirow[t]{2}{*}{ Lost Volume } & \multirow[t]{2}{*}{ Ultrafiltration } & \\
\hline & Before & After & Before & After & & & & \\
\hline & & & & & & & & \\
\hline & & & & & & & & \\
\hline & & & & & & & & \\
\hline & & & & & & & & \\
\hline & & & & & & & & t \\
\hline
\end{tabular}

Figure 1 - Form for the History and Evolution of Nursing of Hemodialysis People

The information on the nursing history form (communicational and semiologic technique) and the nursing evolution were organized in a single page, aiming at an environmental sustainability and a reduction in the number of form matter, both for the form format and for its possibility in format and additional space is provided for recording weight, blood pressure and gain or loss of volume. These data are collected before and after each hemodialysis session (Figure 1).

The second form Nursing Diagnostic List (Figure 2) was organized into three axes: 1) on the left, there are two columns consistent with the structure of Neuman's theory; 2) to the right, there are 14 columns destined to the daily record of the evolution of the nursing diagnoses by means of codes that will indicate the beginning, the accompaniment or the end of a diagnosis; and 3) in the central column, there is a list of possible real, risk or health promotion diagnoses, containing the evidences arising (in) directly from those identified in the literature, and there are additional spaces for the inclusion of diagnoses not listed by cursive registration. 


\begin{tabular}{|c|c|c|c|c|c|c|c|}
\hline & & LIST OF NURSING DIAGNOSES ACCORDING THE NANDA I TAXONOMY FOR PEOPLE UNDER I & IEMODIA & ILYSIS & & & \\
\hline Nan & me: & \begin{tabular}{l|l} 
& Date of birth: \\
\cline { 2 - 2 }
\end{tabular} & Report: & & & lonth/Year & \\
\hline & & Time under hemodialysis: & Day of & the mo & th $\downarrow$ & & \\
\hline & & $\begin{array}{l}\text { Legend: I: diagnosis initially identified C: diagnosis at follow-up T: diagnosis resolved N: diagnosis not } \\
\text { identified Susp: suspense Mod: modified }\end{array}$ & & & & & \\
\hline & & $\begin{array}{l}\text { Excessive fluid volume associated with: } \square \text { compromised regulatory mechanisms; evidenced by: } \square \text { anasarca } \square \\
\text { dispineia } \square \text { sweling } \square \text { electrolytes altered } \square \text { weight gain in short time }\end{array}$ & & & & & \\
\hline & & Risk of infection associated with: $\square$ invasive procedures & & & & & \\
\hline & & Risk for vascular trauma associated with: $\square$ catheter type inadequate catheter fixation & & & & & \\
\hline & & Ineffective protection associated with: $\square$ drug therapy; evidenced by: $\square$ change coagulation $\square$ chills $\square$ pruritus & & & & & \\
\hline & & Fatigue associated with: $\square$ disease state; evidenced by: $\square$ report of fatigue & & & & & \\
\hline & & $\begin{array}{l}\text { Impaired skin integrity associated with: } \square \text { mechanical factors: impaired metabolic state } \square \text { unbalanced nutritional; } \\
\text { evidenced by evidenced by: } \square \text { disruption of the skin surface } \square \text { invasion body structures }\end{array}$ & & & & & \\
\hline & $\frac{T}{Q}$ & $\begin{array}{l}\text { Sexual dysfunction associated with: } \square \text { biopsychosocial alteration } \square \text { sexuality alter altered bodily function; } \\
\text { evidenced by: } \square \text { imitations perceived and imposed by the disease } \square \text { verbalization of the problem }\end{array}$ & & & & & \\
\hline & & $\begin{array}{l}\text { Risk for impaired skin integrity associated with: impaired sensations } \square \text { mechanical factors; state: } \square \text { impaired } \\
\text { metabolic } \square \text { unbalanced nutritional }\end{array}$ & & & & & \\
\hline & & $\begin{array}{l}\text { Intolerance to activity associated with: } \square \text { generalized weakness; evidenced by: } \square \text { discomfort and exertional } \\
\text { dyspnea and verbal reporting (fatigue / weakness) }\end{array}$ & & & & & \\
\hline$\underline{\underline{-}}$ & & Risk of falls associated with: $\square$ visual impairments and impaired physical mobility and orthostatic hypotension & & & & & \\
\hline 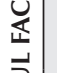 & & $\begin{array}{l}\left({ }^{* *}\right) \text { Provision to perform improved physical activity evidenced by: } \square \text { reporting to enjoy doing physical } \\
\text { activity; } \square \text { disposition to become active }\end{array}$ & & & & & \\
\hline$\frac{1}{5}$ & & Risk of electrolyte imbalance associated with: $\square$ treatment-related side effects & & & & & \\
\hline 崖 & & $\begin{array}{l}\text { Anxiety related to death associated with: } \square \text { perception of the proximity of death; evidenced by: } \square \text { report of } \\
\text { impotence regarding the process of dying }\end{array}$ & & & & & \\
\hline$\frac{\pi}{s}$ & & Insomnia associated with: $\square$ stress; evidenced by: $\square$ report of difficulty falling asleep & & & & & \\
\hline రิֻ & $\approx$ & $\begin{array}{l}\text { Anxiety associated with: situational crises } \square \text { stress evidenced by: } \square \text { restlessness } \square \text { insomnia } \square \text { report of } \\
\text { concerns about the reason for changes in life events }\end{array}$ & & & & & \\
\hline 崖 & & $\begin{array}{l}\text { Ineffective health maintenance associated with: } \square \text { ineffective individual coping; evidenced by: } \square \text { lack of } \\
\text { knowledge of health practices }\end{array}$ & & & & & \\
\hline & & $\begin{array}{l}\text { Disorder in body image associated with: } \square \text { biophysical; evidenced by: } \square \text { report of perceptions that reflect } \\
\text { an altered vision of the body itself }\end{array}$ & & & & & \\
\hline & $u$ & Ineffective role performance associated with: $\square$ physical illness; evidenced by: $\square$ inadequate adaptation to change & & & & & \\
\hline & & $\begin{array}{l}\text { Self-neglect associated with: } \square \text { major stressor of life } \square \text { depression; evidenced by: lack of adherence to } \\
\text { health activity }\end{array}$ & & & & & \\
\hline & & Provision for improved resilience as evidenced by: $\square$ sets goals $\square$ effective use of conflict control strategies & & & & & \\
\hline & & $\begin{array}{l}\text { Impaired individual resilience associated with: } \square \text { vulnerability factors that encompass indexes that } \\
\text { exacerbate the negative effects of the risk condition; evidenced by: } \square \text { perceived health condition as inferior }\end{array}$ & & & & & \\
\hline & 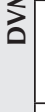 & $\begin{array}{l}\text { Inefficient activity planning associated with: } \square \text { non-realistic perception of personal competence; } \square \\
\text { defensive escape behavior when faced with a proposed solution; evidenced by: } \square \text { lack of a plan; } \square \text { lack of } \\
\text { an appeal; } \square \text { failure in a pattern of behavior }\end{array}$ & & & & & \\
\hline & & $\begin{array}{l}\text { Ineffective denial associated with: } \square \text { fear of death; } \square \text { lack of control over life situation; evidenced by: } \square \\
\text { shifts source of symptoms to other organs }\end{array}$ & & & & & \\
\hline & & Provision for improved self-control of health evidenced by: $\square$ expressed desire to control disease & & & & & \\
\hline & $\approx$ & $\begin{array}{l}\text { Ineffective sexuality pattern associated with: } \square \text { impaired relationship with person; significant evidence of: } \square \\
\text { reporting limitations in sexual behavior }\end{array}$ & & & & & \\
\hline$\approx$ & & $\begin{array}{l}\text { Complicated sorrow associated with: } \square \text { death of significant person; evidenced by: } \square \text { depression; } \square \\
\text { decreased performance in life roles; evidenced by: } \square \text { depression; } \square \text { decreased performance in life roles }\end{array}$ & & & & & \\
\hline 을 & oี & Risk of low situational self-esteem associated with: $\square$ changes in the social role & & & & & \\
\hline 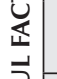 & & $\begin{array}{l}\text { Chronic sadness associated with: } \square \text { death of a loved one; evidenced by negative feelings; } \square \text { that interfere } \\
\text { with the patient's ability to achieve his or her highest level of social well-being }\end{array}$ & & & & & \\
\hline 壳 & & $\begin{array}{l}\text { Poor knowledge associated with: } \square \text { cognitive limitation; } \square \text { lack of exposure; } \square \text { lack of familiarity with } \\
\text { resources / information; evidenced by: } \square \text { verbalization of the problem }\end{array}$ & & & & & \\
\hline 兹 & & Provision for improved knowledge evidenced by: expressed interest in learning; $\square$ demonstrates topic knowledge & & & & & \\
\hline$\sum_{0}^{\frac{1}{z}}$ & & $\begin{array}{l}\text { Poor recreation activity associated with: environmental activity recreation activity; evidenced by: } \square \\
\text { reporting feeling understood }\end{array}$ & & & & & \\
\hline $\mathscr{\sim}$ & & Ineffective relationship risk associated with: $\square$ stressful life events; $\square$ unsatisfactory communication skills & & & & & \\
\hline 訔 & $\omega$ & $\begin{array}{l}\text { Provision for improved relationship evidenced by: } \square \text { reports satisfaction with the complementary } \\
\text { relationship between the partners }\end{array}$ & & & & & \\
\hline & & $\begin{array}{l}\text { Provision for improved family processes evidenced by: } \square \text { family functioning meets the needs of family members; } \\
\text { ties between family members are maintained }\end{array}$ & & & & & \\
\hline & & $\begin{array}{l}\text { Impaired social interaction associated with: } \square \text { deficiency in strengthening mutuality; evidenced by: } \square \\
\text { dysfunctional interaction with other people; ability to receive a satisfactory sense of social involvement }\end{array}$ & & & & & \\
\hline
\end{tabular}

To be continued 


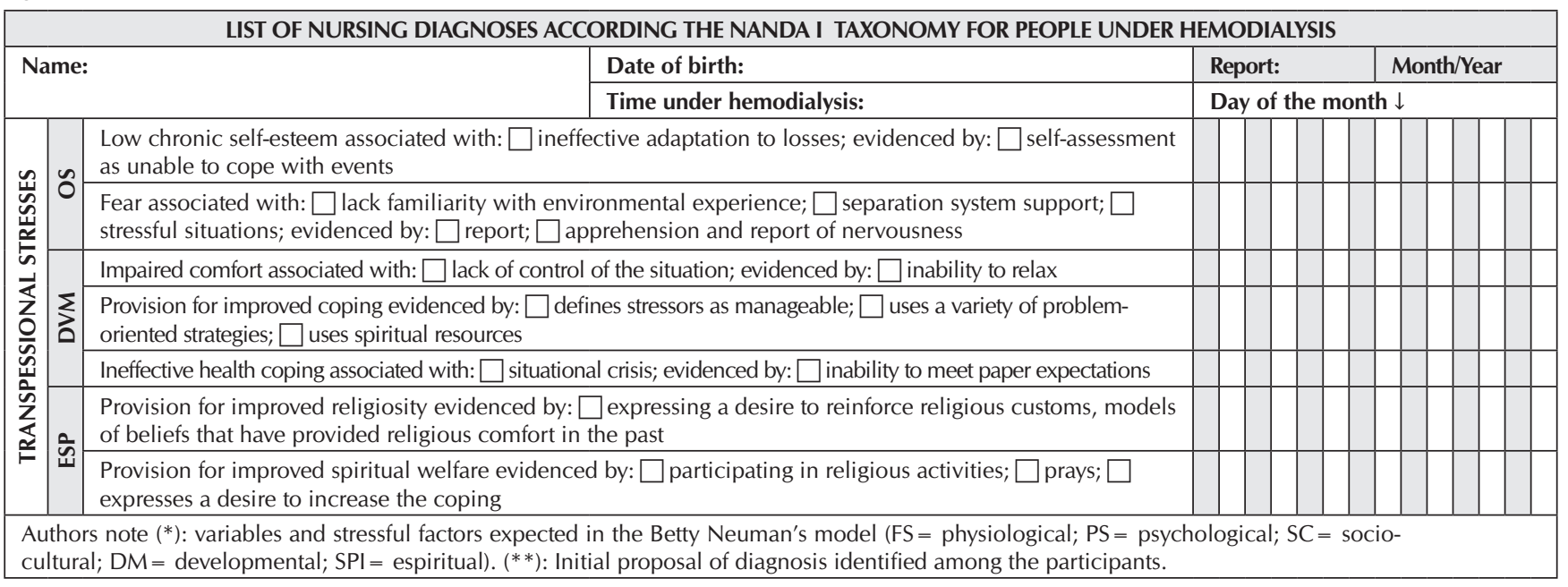

Figure 2 - Form for the History and Evolution of Nursing of Hemodialysis People

A total of 43 nursing diagnoses were identified among 18 people on hemodialysis, using the NANDA I taxonomy ${ }^{(8)}, 27$ of which were of the real type, seven of risk and nine of health promotion.

The most prevalent diagnoses were: limitation of social and family coexistence due to the time spent in substitute renal therapies and the restrictions imposed by them; the presence of the AVF or the venous catheter, which evidence the disease and the risk of acquiring infections, as well as interfere with the hygiene habits and situations of dependency of the relatives/people of reference or caregivers to perform activities self-care. The diagnoses listed rescue a set of situations that portray the profile of problems/ situations shared among people on hemodialysis.

We identified some nursing diagnoses that were repeated more frequently among participants, such as: excessive fluid volume; risk of infection; activity intolerance; anxiety; self-neglect; impaired comfort; impaired social interaction; and ineffective coping.

The nursing diagnoses form was structured to allow the individualized approach, characterization of the demands of interventions and nursing results (Figure 3). Its structured three-axis format was a strategy to reduce the documentation to be archived (when printed) and monitor the evolution of the diagnoses during the 14 sessions of hemodialysis and / or monthly evaluations.
The third form entitled Nursing Interventions and Results (Figure 3) made it possible to reaffirm 26 interventions and 78 outcome indicators with their respective measurable scales from clinical practice and expert support. The scales contain values ranging from one to five, with a value of five representing the best possible condition.

Nursing interventions and outcomes, according to $\mathrm{NIC}^{(8)}$ and $\mathrm{NOC}^{(9)}$, were grouped in the same form to make it possible to: make a layout compatible and optimize space; give speed to completion of registration; facilitate handling and link interventions to outcome indicators (measurable scales), with room for them (Figure 3). The criterion adopted was the guarantee of the specification of the general guidelines to define the therapeutic behavior, the indicators and the measurable scales for each item.

There were criteria for layout adequacy: to match the maximum of information in the minimum of possible space and to gather information standards according to the variables contemplated in the layers of the system of energies advocated by the theory of Neuman. A layout compatible with the compaction of the nursing records was obtained, with a comparative analysis between the stages of the nursing process and that allowed to check the coherence between the alignments of the taxonomic elements used (NNN).

\begin{tabular}{|c|c|c|c|c|c|c|c|}
\hline & NURSING INTER & VENTIONS AND RE & SULTS BY & NIC AND NOC & R PATIENTS UNDER HEMC & DIALYSIS & \\
\hline Name & & & & Date & oirth: & Month/Y & ear: \\
\hline Repor & & & & Time & der hemodialysis: & & \\
\hline NIC & Results (NOC) & Scale: Indicators & Schedule & NIC & Results (NOC) & Scale: Indicators & Schedule \\
\hline $\begin{array}{l}\text { Advance } \\
\text { Guidance }\end{array}$ & $\begin{array}{l}\text { Precautions against } \\
\text { disease complications }\end{array}$ & $\square 1 \square 2 \square 3 \square 4 \square 5$ & & $\begin{array}{l}\text { Modifying } \\
\text { behavior: social }\end{array}$ & $\begin{array}{l}\text { Reports feeling socially } \\
\text { engaged }\end{array}$ & $\square 1 \square 2 \square 3 \square 4 \square 5$ & \\
\hline & $\begin{array}{l}\text { Diet plan for social } \\
\text { situations }\end{array}$ & $\square 1 \square 2 \square 3 \square 4 \square 5$ & & & $\begin{array}{l}\text { Verbalizes feeling better } \\
\text { control }\end{array}$ & $\square 1 \square 2 \square 3 \square 4 \square 5$ & \\
\hline & $\begin{array}{l}\text { Self-monitoring } \\
\text { techniques }\end{array}$ & $\square 1 \square 2 \square 3 \square 4 \square 5$ & & & $\begin{array}{l}\text { Withdrawal from abusive } \\
\text { situations }\end{array}$ & $\square 1 \square 2 \square 3 \square 4 \square 5$ & \\
\hline & Advantages of diet & $\square 1 \square 2 \square 3 \square 4 \square 5$ & & & Diet advantages & $\square 1 \square 2 \square 3 \square 4 \square 5$ & \\
\hline & $\begin{array}{l}\text { Responsibility for self-care } \\
\text { in continuous treatment }\end{array}$ & $\square 1 \square 2 \square 3 \square 4 \square 5$ & & & Foods to Avoid & $\square 1 \square 2 \square 3 \square 4 \square 5$ & \\
\hline
\end{tabular}


Figure 3

\begin{tabular}{|c|c|c|c|c|c|c|c|}
\hline \multicolumn{8}{|c|}{ NURSING INTERVENTIONS AND RESULTS BY NIC AND NOC FOR PATIENTS UNDER HEMODIALYSIS } \\
\hline \multicolumn{2}{|l|}{ Name: } & \multicolumn{4}{|c|}{ Date of birth: } & \multicolumn{2}{|c|}{ Month/Year: } \\
\hline \multicolumn{2}{|l|}{ Report: } & \multicolumn{6}{|c|}{ Time under hemodialysis: } \\
\hline NIC & Results (NOC) & Scale: Indicators & Schedule & NIC & Results (NOC) & Scale: Indicators & Schedule \\
\hline \multirow[t]{9}{*}{$\begin{array}{l}\text { Coping } \\
\text { improvement }\end{array}$} & $\begin{array}{l}\text { Recognition reality health } \\
\text { situation }\end{array}$ & $\square 1 \square 2 \square 3 \square 4 \square 5$ & & \multirow{2}{*}{$\begin{array}{l}\text { Modifying } \\
\text { behavior: social } \\
\text { skills }\end{array}$} & Liquids and food allowed & $\square 1 \square 2 \square 3 \square 4 \square 5$ & \\
\hline & $\begin{array}{l}\text { Identifying Effective } \\
\text { Coping Patterns }\end{array}$ & $\square 1 \square 2 \square 3 \square 4 \square 5$ & & & $\begin{array}{l}\text { Strategies for changing } \\
\text { eating habits }\end{array}$ & $\square 1 \square 2 \square 3 \square 4 \square 5$ & \\
\hline & $\begin{array}{l}\text { Psychological comfort } \\
\text { increase report }\end{array}$ & $\square 1 \square 2 \square 3 \square 4 \square 5$ & & \multirow[t]{2}{*}{$\begin{array}{l}\text { Protection } \\
\text { against infection }\end{array}$} & Infection control practice & $\square 1 \square 2 \square 3 \square 4 \square 5$ & \\
\hline & $\begin{array}{l}\text { Uses effective coping } \\
\text { strategies }\end{array}$ & $\square 1 \square 2 \square 3 \square 4 \square 5$ & & & $\begin{array}{l}\text { Recognition of behaviors } \\
\text { associated with risk of } \\
\text { infection }\end{array}$ & $\square 1 \square 2 \square 3 \square 4 \square 5$ & \\
\hline & $\begin{array}{l}\text { Reports feeling socially } \\
\text { engaged }\end{array}$ & $\square 1 \square 2 \square 3 \square 4 \square 5$ & & \multirow[t]{2}{*}{$\begin{array}{l}\text { Risk } \\
\text { identification }\end{array}$} & $\begin{array}{l}\text { Identification of potential } \\
\text { health risks }\end{array}$ & $\square 1 \square 2 \square 3 \square 4 \square 5$ & \\
\hline & $\begin{array}{l}\text { Interaction with family } \\
\text { members }\end{array}$ & $\square 1 \square 2 \square 3 \square 4 \square 5$ & & & $\begin{array}{l}\text { Precautions to prevent } \\
\text { disease complications }\end{array}$ & $\square 1 \square 2 \square 3 \square 4 \square 5$ & \\
\hline & Maintains productivity & $\square 1 \square 2 \square 3 \square 4 \square 5$ & & \multirow{4}{*}{$\begin{array}{l}\text { Improvement } \\
\text { in the support } \\
\text { system }\end{array}$} & $\begin{array}{l}\text { Searches for emotional } \\
\text { support }\end{array}$ & $\square 1 \square 2 \square 3 \square 4 \square 5$ & \\
\hline & $\begin{array}{l}\text { Uses effective financial } \\
\text { control strategy }\end{array}$ & $\square 1 \square 2 \square 3 \square 4 \square 5$ & & & $\begin{array}{l}\text { Participation as } \\
\text { a member of an } \\
\text { organization }\end{array}$ & $\square 1 \square 2 \square 3 \square 4 \square 5$ & \\
\hline & $\begin{array}{l}\text { Uses social support } \\
\text { available }\end{array}$ & $\square 1 \square 2 \square 3 \square 4 \square 5$ & & & $\begin{array}{l}\text { Participation with a } \\
\text { member of a church }\end{array}$ & $\square 1 \square 2 \square 3 \square 4 \square 5$ & \\
\hline \multirow[t]{5}{*}{$\begin{array}{l}\text { Emotional } \\
\text { Support }\end{array}$} & Assistance from others & $\square 1 \square 2 \square 3 \square 4 \square 5$ & & & $\begin{array}{l}\text { Interaction with closest } \\
\text { friends }\end{array}$ & $\square 1 \square 2 \square 3 \square 4 \square 5$ & \\
\hline & Time provided by others & $\square 1 \square 2 \square 3 \square 4 \square 5$ & & \multirow[t]{3}{*}{$\begin{array}{l}\text { Control } \\
\text { behavior }\end{array}$} & $\begin{array}{l}\text { Receptivity } \\
\text { demonstration }\end{array}$ & $\square 1 \square 2 \square 3 \square 4 \square 5$ & \\
\hline & Trusts & $\square 1 \square 2 \square 3 \square 4 \square 5$ & & & $\begin{array}{l}\text { Use of assertive } \\
\text { behaviors if necessary }\end{array}$ & $\square 1 \square 2 \square 3 \square 4 \square 5$ & \\
\hline & People help when needed & $\square 1 \square 2 \square 3 \square 4 \square 5$ & & & $\begin{array}{l}\text { Consideration } \\
\text { demonstration }\end{array}$ & $\square 1 \square 2 \square 3 \square 4 \square 5$ & \\
\hline & $\begin{array}{l}\text { Self-care responsibility: } \\
\text { continuous treatment }\end{array}$ & $\square 1 \square 2 \square 3 \square 4 \square 5$ & & Support group & $\begin{array}{l}\text { Search for emotional } \\
\text { support }\end{array}$ & $\square 1 \square 2 \square 3 \square 4 \square 5$ & \\
\hline \multirow[t]{7}{*}{$\begin{array}{l}\text { Exercise } \\
\text { promotion }\end{array}$} & $\begin{array}{l}\text { Movements easily } \\
\text { performed }\end{array}$ & $\square 1 \square 2 \square 3 \square 4 \square 5$ & & \multirow[t]{6}{*}{$\begin{array}{l}\text { Improvement of } \\
\text { body image }\end{array}$} & Coping & $1 \square 2 \square 3 \square 4 \square 5$ & \\
\hline & Activity & $\square 1 \square 2 \square 3 \square 4 \square 5$ & & & Body image & $\square 1 \square 2 \square 3 \square 4 \square 5$ & \\
\hline & Muscle resistance & $\square 1 \square 2 \square 3 \square 4 \square 5$ & & & Personal autonomy & $\square 1 \square 2 \square 3 \square 4 \square 5$ & \\
\hline & Hemoglobin & $\square 1 \square 2 \square 3 \square 4 \square 5$ & & & $\begin{array}{l}\text { Psychological adjustment } \\
\text { to life change }\end{array}$ & $\square 1 \square 2 \square 3 \square 4 \square 5$ & \\
\hline & Hematocrit & $\square 1 \square 2 \square 3 \square 4 \square 5$ & & & Self-esteem & $\square 1 \square 2 \square 3 \square 4 \square 5$ & \\
\hline & Blood glucose & $\square 1 \square 2 \square 3 \square 4 \square 5$ & & & Personal resilience & $\square 1 \square 2 \square 3 \square 4 \square 5$ & \\
\hline & Serum electrolytes & $\square 1 \square 2 \square 3 \square 4 \square 5$ & & \multirow{5}{*}{$\begin{array}{l}\text { Strengthening } \\
\text { self-esteem }\end{array}$} & Maintains self-esteem & $\square 1 \square 2 \square 3 \square 4 \square 5$ & \\
\hline \multirow[t]{4}{*}{$\begin{array}{l}\text { Familiar } \\
\text { mobilization }\end{array}$} & Assistance from others & $\square 1 \square 2 \square 3 \square 4 \square 5$ & & & $\begin{array}{l}\text { Uses well coping } \\
\text { strategies }\end{array}$ & $\square 1 \square 2 \square 3 \square 4 \square 5$ & \\
\hline & Time provided by others & $\square 1 \square 2 \square 3 \square 4 \square 5$ & & & $\begin{array}{l}\text { Expresses optimism } \\
\text { about the future }\end{array}$ & $\square 1 \square 2 \square 3 \square 4 \square 5$ & \\
\hline & Trusts & $\square 1 \square 2 \square 3 \square 4 \square 5$ & & & Report feeling empowered & $\square 1 \square 2 \square 3 \square 4 \square 5$ & \\
\hline & People help when needed & $\square 1 \square 2 \square 3 \square 4 \square 5$ & & & Psychosocial Adaptation & $\square 1 \square 2 \square 3 \square 4 \square 5$ & \\
\hline \multirow{4}{*}{$\begin{array}{l}\text { Promotion } \\
\text { of family } \\
\text { involvement }\end{array}$} & $\begin{array}{l}\text { Interaction with family } \\
\text { members }\end{array}$ & $\square 1 \square 2 \square 3 \square 4 \square 5$ & & \multirow[t]{4}{*}{ Spiritual support } & $\begin{array}{l}\text { State of comfort: psycho- } \\
\text { spiritual }\end{array}$ & $\square 1 \square 2 \square 3 \square 4 \square 5$ & \\
\hline & People help when needed & $\square 1 \square 2 \square 3 \square 4 \square 5$ & & & Faith & $\square 1 \square 2 \square 3 \square 4 \square 5$ & \\
\hline & Assistance from others & $\square 1 \square 2 \square 3 \square 4 \square 5$ & & & Spiritual satisfaction & $\square 1 \square 2 \square 3 \square 4 \square 5$ & \\
\hline & Time provided by others & $\square 1 \square 2 \square 3 \square 4 \square 5$ & & & Psychological well-being & $\square 1 \square 2 \square 3 \square 4 \square 5$ & \\
\hline
\end{tabular}




\begin{tabular}{|c|c|c|c|c|c|c|c|}
\hline \multicolumn{8}{|c|}{ NURSING INTERVENTIONS AND RESULTS BY NIC AND NOC FOR PATIENTS UNDER HEMODIALYSIS } \\
\hline \multicolumn{2}{|l|}{ Name: } & \multicolumn{4}{|c|}{ Date of birth: } & \multicolumn{2}{|c|}{ Month/Year: } \\
\hline \multicolumn{2}{|c|}{ Report: } & \multicolumn{6}{|c|}{ Time under hemodialysis: } \\
\hline NIC & Results (NOC) & Scale: Indicators & Schedule & NIC & Results (NOC) & Scale: Indicators & Schedule \\
\hline \multirow{2}{*}{$\begin{array}{l}\text { Electrolytic } \\
\text { control }\end{array}$} & Water balance & $\square 1 \square 2 \square 3 \square 4 \square 5$ & & \multirow{4}{*}{$\begin{array}{l}\text { Sexual } \\
\text { Counseling }\end{array}$} & Role performance & $\square 1 \square 2 \square 3 \square 4 \square 5$ & \\
\hline & Stable body weight & $\square 1 \square 2 \square 3 \square 4 \square 5$ & & & $\begin{array}{l}\text { Role performance } \\
\text { expectations }\end{array}$ & $\square 1 \square 2 \square 3 \square 4 \square 5$ & \\
\hline \multirow{4}{*}{$\begin{array}{l}\text { Teaching: } \\
\text { Activity / } \\
\text { Prescribed } \\
\text { Exercise }\end{array}$} & $\begin{array}{l}\text { Description of activity } \\
\text { precautions }\end{array}$ & $\square 1 \square 2 \square 3 \square 4 \square$ & & & $\begin{array}{l}\text { Uses well coping } \\
\text { strategies }\end{array}$ & $\square 1 \square 2 \square 3 \square 4 \square 5$ & \\
\hline & Realistic workout plan & $\square 1 \square 2 \square 3 \square 4 \square 5$ & & & $\begin{array}{l}\text { Role performance in } \\
\text { intimacy }\end{array}$ & $\square 1 \square 2 \square 3 \square 4 \square 5$ & \\
\hline & Behavior of adhesion & $\square 1 \square 2 \square 3 \square 4 \square 5$ & & \multirow{4}{*}{$\begin{array}{l}\text { Encouragement } \\
\text { of religious } \\
\text { rituals }\end{array}$} & $\begin{array}{l}\text { State of comfort: psycho- } \\
\text { spiritual }\end{array}$ & $\square 1 \square 2 \square 3 \square 4 \square 5$ & \\
\hline & $\begin{array}{l}\text { Considers risk / health } \\
\text { behavior benefits }\end{array}$ & $\square 1 \square 2 \square 3 \square 4 \square 5$ & & & Faith & $\square 1 \square 2 \square 3 \square 4 \square 5$ & \\
\hline \multirow{2}{*}{$\begin{array}{l}\text { Teaching } \\
\text { Disease } \\
\text { process }\end{array}$} & $\begin{array}{l}\text { Knowledge: Disease } \\
\text { processes }\end{array}$ & $\square 1 \square 2 \square 3 \square 4 \square 5$ & & & Spiritual satisfaction & $\square 1 \square 2 \square 3 \square 4 \square 5$ & \\
\hline & $\begin{array}{l}\text { Description of the disease } \\
\text { process }\end{array}$ & $\square 1 \square 2 \square 3 \square 4 \square 5$ & & & Psychological well-being & $\square 1 \square 2 \square 3 \square 4 \square 5$ & \\
\hline \multirow{4}{*}{$\begin{array}{l}\text { Teaching: } \\
\text { Prescribed } \\
\text { Diet }\end{array}$} & Advantages of diet & $\square 1 \square 2 \square 3 \square 4 \square 5$ & & \multirow{3}{*}{$\begin{array}{l}\text { Self-care } \\
\text { essential } \\
\text { activities of } \\
\text { daily living }\end{array}$} & Self-care: DLA & $\square 1 \square 2 \square 3 \square 4 \square 5$ & \\
\hline & Foods to Avoid & $\square 1 \square 2 \square 3 \square 4 \square 5$ & & & $\begin{array}{l}\text { Performance of domestic } \\
\text { work }\end{array}$ & $\square 1 \square 2 \square 3 \square 4 \square 5$ & \\
\hline & $\begin{array}{l}\text { Strategy to change eating } \\
\text { habits }\end{array}$ & $\square 1 \square 2 \square 3 \square 4 \square 5$ & & & $\begin{array}{l}\text { Performing gardening } \\
\text { tasks }\end{array}$ & $\square 1 \square 2 \square 3 \square 4 \square 5$ & \\
\hline & Liquids and food allowed & $\square 1 \square 2 \square 3 \square 4 \square 5$ & & \multirow[t]{3}{*}{ Fall Prevention } & Fall prevention & $\square 1 \square 2 \square 3 \square 4 \square 5$ & \\
\hline \multirow[t]{4}{*}{ Counseling } & $\begin{array}{l}\text { Adaptation / changes } \\
\text { physical appearance }\end{array}$ & $\square 1 \square 2 \square 3 \square 4 \square 5$ & & & $\begin{array}{l}\text { When requesting } \\
\text { personal assistance }\end{array}$ & $\square 1 \square 2 \square 3 \square 4 \square 5$ & \\
\hline & $\begin{array}{l}\text { Adaptation / changes on } \\
\text { health status }\end{array}$ & $\square 1 \square 2 \square 3 \square 4 \square 5$ & & & $\begin{array}{l}\text { Strategies to get around } \\
\text { with safely }\end{array}$ & $\square 1 \square 2 \square 3 \square 4 \square 5$ & \\
\hline & $\begin{array}{l}\text { Family support during } \\
\text { treatment }\end{array}$ & $\square 1 \square 2 \square 3 \square 4 \square 5$ & & $\begin{array}{l}\text { Facilitating the } \\
\text { sorrow process }\end{array}$ & $\begin{array}{l}\text { Coping Personal } \\
\text { resilience }\end{array}$ & $\square 1 \square 2 \square 3 \square 4 \square 5$ & \\
\hline & $\begin{array}{l}\text { Family members comfort } \\
\text { offer }\end{array}$ & $\square 1 \square 2 \square 3 \square 4 \square 5$ & & & $\begin{array}{l}\text { Positive self-esteem and } \\
\text { display }\end{array}$ & $\square 1 \square 2 \square 3 \square 4 \square 5$ & \\
\hline \multirow{3}{*}{$\begin{array}{l}\text { Promotion } \\
\text { Capacity } \\
\text { Resilience }\end{array}$} & $\begin{array}{l}\text { Use of effective coping } \\
\text { strategies }\end{array}$ & $\square 1 \square 2 \square 3 \square 4 \square 5$ & & & Progress towards goals & $\square 1 \square 2 \square 3 \square 4 \square 5$ & \\
\hline & Others, specify & $\square 1 \square 2 \square 3 \square 4 \square 5$ & & & Others, specify & $\square 1 \square 2 \square 3 \square 4 \square 5$ & \\
\hline & & $\square 1 \square 2 \square 3 \square 4 \square 5$ & & & & $\square 1 \square 2 \square 3 \square 4 \square 5$ & \\
\hline
\end{tabular}

Note: Write indicators using DC (characteristics that define the real diagnoses) or the RF (related factor of the risk diagnoses).

Figure 3 - Printed for registration of nursing interventions and results in people on hemodialysis (forward and backward)

\section{DISCUSSION}

Chronic kidney disease, hemodialysis patients, and lifestyle changes constituted stresses, that is, stresses that produced changes in normal energy flow and were expressed in the following dimensions: intrapersonal (man being spiritual and psychological ); interpersonal (man being social) and extrapersonal (environmental factors) ${ }^{(6)}$.

In this sense, the individual was perceived as a system of forces, influenced by physiological, psychological, sociocultural, spiritual and developmental variables that, when captured in an integrated and articulated way in the same theoretical model, enabled the data collection instrument of nursing to instrumentalize the nurse for the access to the stressors that generated (dis) balance in the organism to the point of portraying the health / illness continuum ${ }^{(6)}$.

All forms were able to capture the internal (intrapersonal) and external (interpersonal and extrapersonal) stressors ${ }^{(6)}$, which constitute a thermometer to identify the emerging problems and at what point the nursing needed to intervene.

In its structure, the data collection instrument was designed to capture information from hemodialysis patients and their relatives from the user's perspective. It was also possible to understand the current and previous conditions of health, to recover the itinerary and therapeutic behaviors, to capture the coping before hemodialysis and to shelter additional 
information, based on the adopted references ${ }^{(6-9)}$ and theoretical knowledge $\mathrm{k}^{(2-4)}$ and clinical knowledge renal disease $\mathrm{e}^{(14)}$ and renal replacement therapy ${ }^{(2)}$. This concern was due to the need to portray the profile of demands for nursing care.

The contents were structured according to the assumptions and divisions of the selected theory ${ }^{(6)}$ in order to: 1) capture environmental stimuli by living with therapeutic technology, institutional routine, hemodialysis treatment and change in lifestyle; 2) to obtain the perception of the users for the situations considered stressful in the coexistence with professionals, relatives, friends, (dis) acquaintances and companions of treatment; and 3) identify the reactions of individuals to internal stressors, such as personality and coping with adversity.

In their structure, the form material makes it possible to capture evidence, signs, symptoms and manifestations that characterize the profile of people undergoing hemodialysis, such as dietary restrictions and time required to effect treatment $t^{(3,15-16)}$.

Stressors such as coexistence with the possibility of death, adherence or not to renal transplantation, and follow-up of the (in) compatibility result for transplantation are corroborated with evidence from the literature ${ }^{(2,14-15)}$, being considered peculiar to the presence of other stressors impaired renal function, hemodialysis machine dependence for blood clearance, availability of time for the sessions, changes in daily habits / behaviors, and uncertainty about whether or not a relative is positioned to be a donor or queue).

The list of possible nursing diagnoses according to the NANDA I taxonomy ${ }^{(7)}$ was designed to make layout compatible; rapidity of completion, procedural follow-up of the evolution of the diagnoses and explanation of all the components of each diagnosis (causes, risk factors and clinical manifestations) and guided simultaneously the choice of nursing interventions and the explanation of the results indicators used in the evolution of nursing, contributing to the improvement of nursing records $\mathrm{s}^{(17)}$.

To reconcile the priorities of demands for care and emerging needs with the organization of contents according to the theoretical-philosophical model of Neuman ${ }^{(6)}$ and the eligible taxonomic approaches - $N N^{(7-9)}$, was a criterion for the presentation of nursing diagnoses. The experience of adjusting the diagnoses by the axes of the intrapersonal variables sought to take into account the recommendation of the systematization process of care ${ }^{(10)}$ and facilitated its handling by the nurses.

The focus group was able to obtain / reaffirm information and identify that the printouts were able to capture the demands of care in an individualized way from the answers of the people under hemodialysis. The pertinence of the use of the focal group technique was corroborated by another study, in which it favored sensitizing the participants, stimulating their participation by motivating the group to the theme proposed for discussion ${ }^{(13)}$.

The number of nursing interventions and outcome indicators identified among the 18 people under hemodialysis translated the diversity of stressors to which they are exposed. It was possible to identify the impact of people's responses to internal and external stressors ${ }^{(6)}$ and reactions to them from the interpretation of the basic factors that make up the human being adopted by Neuman (physiological, psychological, sociocultural, developmental, spiritual and concentric lines) ${ }^{(6)}$ and which were listed individually for each type of diagnosis.

The problems identified from the nuclear situations of renal replacement therapy due to hemodialysis justify the demands of intrapersonal and physiological origin, and the deprivations, restrictions and dependencies arising from renal replacement therapy justify interpersonal problems and their impact on sociocultural and psychological variables ${ }^{(12,17-18)}$.

The defining characteristics and the risk factors evidenced in the nursing diagnosis instrument (Picture 2) guided the identification of the problems, as well as the title of the diagnosis favored the identification of the therapeutic goals, assisting in the selection of nursing interventions. Such information subsidized the collection of pertinent interventions to solve each problem and allowed the selection of the most appropriate indicators to evaluate nursing outcomes ${ }^{(7-9)}$.

The search for nursing interventions in the light of the identification of the stressors facilitated the selection of nursing care that favored the adaptation of the individual to the point of avoiding that the stressors penetrated the normal line of defense, strengthening the lines of resistance to reduce the reaction of the individual to the stressor, as well as to prevent future occurrences ${ }^{(6)}$.

The choice of interventions ${ }^{(8)}$ and nursing outcomes ${ }^{(9)}$ were prioritized according to nuclear situations ${ }^{(2-4)}$. A nuclear situation was conceived in the present investigation as one that: 1) derives directly from the CKD and the problems arising from the progressive and irreversible loss of kidney function and occurs when they are unable to remove the products from the degradation metabolism of the body or to perform its regulatory functions ${ }^{(2-4,14)}$; and 2 ) it is directly related to hemodialysis, whose average duration is four hours / day on three days in the week and operated by means of an AVF or a double lumen catheter ${ }^{(15)}$; and 3) it is a stressor for the person with renal disorder or their family member (s).

The structuring of each form made it possible to capture the demands of human needs and care; define emerging problems compatible with nursing work performance; to subsidize the process of clinical reasoning; and to identify the indicators to evaluate the therapeutic interventions of the nursing team. This fact filled a previously identified gap in the use of form matter constructed for a given reality and was able to direct the nurse's look to the questions of technical, scientific and philosophical pertinence of his role in a specialty of renal replacement therapy ${ }^{(19)}$. From the legal point of view, the form material guides the pertinent contents that need to be recorded and documented when an individualized care is sought and capable of capturing the specificities of the human responses of those under hemodialysis.

The process of construction of the forms enabled the sharing of experiences, discussions of therapeutic behaviors, definition of markers of evaluation and their consensus from the chosen reference points (Betty Neuman theory, use / handling of NNN taxonomies and therapeutic approach for people under hemodialysis) ${ }^{(5-9)}$.

The contents of the forms were in line with scientific evidence consistent with the approach of the subject and with Resolution 358/2009(10) of the Brazilian Federal Nursing Council, to the point of contemplating normative, legal and operational recommendations for the labor activities of the category. Clear contents (signs and symptoms), situations of 
vulnerability and causal factors (etiology or etiopathology) were obtained, which later, through clinical reasoning, allowed its transposition to the NNN taxonomies ${ }^{(7-9)}$.

\section{Study limitation}

It occurred for the application in a Brazilian reality that can be overcome with the validation of the form ones in other contexts.

\section{Contribution of the study for the nursing, health and pub-} lic politics

The contribution of the present study was the construction of form material to subsidize the health care of people who undergo hemodialysis in a specialized public health service, presenting the most common vulnerability situations. The use of the forms elaborated in this study provides a reflexive critical thinking and subsidizes the diagnostic decision process in the labor practice.

The methodological trajectory made it possible to fill gaps in the literature on the subject, to consider identified needs among hemodialysis patients when attending a specialized service, and to validate the contents, layout of the form matter and its pertinence to capture individualized situations among hemodialysis patients.

\section{FINAL CONSIDERATIONS}

The construction of the forms using Neuman's theory made it possible to identify stressors capable of acting on the physiological, psychological, sociocultural, developmental and spiritual structure of the people under hemodialysis enabled the use of NNN taxonomies and the standardization of the lexical components of the nursing language.

The application of the forms in a hemodialysis sector allowed to identify situations arising from: changes in habits and routines; possibility of death; emergence of conflicts; configuring the family and social life and resizing the conception of life, using standardized language that can be shared by nurses of different nationalities and thus, operationalize the systematization of nursing care in hemodialysis sectors.

The present research allowed gathering cognitive abilities (analysis, application of patterns, discernment, information search, logical reasoning, prediction and transformation of knowledge) and mental habits (trust, contextual perspective, creativity, flexibility, intellectual integrity, intuition, and reflection). It should be noted that this strategy for the construction of the forms for the systematization of nursing care constituted a process of permanent education for the participants.

\section{ACKNOLEDGEMENTS}

We thank the nurses of the hemodialysis service who participated in the focus group and contributed to the improvement of the form matter, and to the patients who participated in the data collection and made possible the construction and validation of the form matter.

\section{REFERENCES}

1. Sociedade Brasileira de Nefrologia. Censo de diálise: SBN 2013 [Internet]. 2013 [cited 2015 Sep 13]. Available from: http://www. sbn.org.br/censos

2. Andrade SV, Sesso R, Diniz DHMP. Hopelessness, suicide ideation, and depression in chronic kidney disease patients on hemodialysis or transplant recipients. J Bras Nefrol [Internet]. 2015 [cited 2015 Sep 13];37(1):55-63. Available from: http://www. scielo.br/pdf/jbn/v37n1/en_0101-2800-jbn-37-01-0055.pdf

3. Lira CLOB, Avelar TC, Bueno JMMH. [Coping and quality of life of the patients in hemodialysis]. Est Interdisc Psic [Internet]. 2015[cited 2015 Sep 13];6(1):82-99. Available from: http://www.uel.br/revistas/uel/index.php/eip/article/view/21464/16763 Portuguese

4. Frazão CMFQ, Araújo MGA, Tinôco JDS, Delgado MF, Kadyjina DBL, Lira ALBC. Defined characteristics of the nursing diagnosis identified on individuals in hemodialysis. Cienc Cuid Saude [Internet]. 2015[cited 2015 Sep 28];14(2):1157-64. Available from: http://periodicos.uem.br/ojs/index.php/CiencCuidSaude/article/view/22906

5. Barbosa GDS, Valadares GV. Becoming proficient: knowledge and practice of hemodialysis nurses. Esc. Anna Nery Rev Enferm [Internet]. 2014[cited 2015 Sep 15];18(1):163-6. Available from: http://dx.doi.org/10.5935/1414-8145.20140024

6. Neuman B, Fawcett J. The Neuman Systems Model. 5 th ed. Prentice Hall; 2010.

7. Herdman TH, Kamitsuru S. NANDA International Nursing diagnoses: definitions and classification, 2015-2017. Oxford: WileyBlackwell; 2015.

8. Bulechek GM, Butcher HK, Dochterman JM. Classificação das intervenções de enfermagem (NIC). 6 ed. Denise Costa Rodrigues. (Trad.). Rio de Janeiro: Elsevier; 2016.

9. Moorhead S, Johnson M, Maas M, Swanson E. Classificação dos resultados de enfermagem: mensuração dos resultados em saúde (NOC). Rio de Janeiro: Elsevier; 2016.

10. Brasil. Conselho Federal de Enfermagem (COFEN). Resolução 358, de 23 de outubro de 2009: Dispõe sobre a Sistematização da Assistência de Enfermagem e a implementação do processo de Enfermagem em ambientes públicos ou privados, em que ocorre o cuidado profissional de Enfermagem, e dá outras providências. Brasília (Br): 2009.

11. Tannure MC, Salgado PO, Chianca TCM. [Cross-Mapping: diagnostic labels formulated according to the ICNP ${ }^{\circledR}$ versus diagnosis 
of NANDA International]. Rev Bras Enferm [Internet]. 2014[cited 2015 Sep 17];67(6):972-8. Available from: http://www.scielo.br/ pdf/reben/v67n6/0034-7167-reben-67-06-0972.pdf Portuguese

12. Christensen PJ, Kenney JW. (Eds). Nursing process: application of conceptual models. 4a ed. St. Louis: Mosby; 1995. 367p

13. Soares MI, Camelo SHH, Resck ZMR. A técnica de grupo focal na coleta de dados qualitativos: relato de experiência. REME [Internet]. 2016 [cited 2017 Feb 29];20:e942. Available from: https://dx.doi.org/10.5935/1415-2762.20160012

14. Munaretto LF, Corrêa LH, Cunha JAC. [A study on the characteristics of the Delphi method and focus group as techniques to obtain data in exploratory research]. Rev Adm UFSM [Internet]. 2013[cited 2015 Sep 18];6(1):9-24. Available from: http://cascavel.ufsm. br/revistas/ojs-2.2.2/index.php/reaufsm/article/view/6243 Portuguese

15. Johnson M, Moorhead S, Butcher HK, Maas ML, Swanson E. Ligações entre NANDA, NOC e NIC. Rio de Janeiro: Elsevier Brasil; 2012.

16. Roso CC, Beuter M, Bruinsma JL, Silva JH, Timm AMB, Pauletto MR. [Clinical aspects of people with chronic renal failure in conservative treatment]. Rev Rene [Internet]. 2014[cited 2015 Sep 17];14(6):1201-8. Available from: http://www.revistarene.ufc. br/revista/index.php/revista/article/view/1380/pdf. Portuguese

17. Moraes A, Cintra KTGV, Cintra HDE, Braz E. [The daily life of chronic renal patients submitted to outpatient treatment hemodialysis]. UDESC Ação[Internet]. 2014 [cited 2015 Sep 18];8(2):87-99. Available from: http://www.revistas.udesc.br/index. php/udescemacao/issue/current/showToc Portuguese.

18. Silva $L M D$, Bueno $C D$. [Adherence to dietary treatment from the perspective of patients with chronic renal failure on hemodialysis]. Nutrire Rev Soc Bras [Internet]. 2014[cited 2015 Sep 18];39(3):276-83. Available from: http://revistanutrire.org.br/doi/10.4322/ nutrire Portuguese.

19. Santos CM, Kirchmaier FM, Silveira WJ, Arreguy-Sena C. Percepções de enfermeiros e clientes sobre cuidados de enfermagem no transplante de rim. Acta Paul Enferm [Internet]. 2015[cited 2015 Sep 13];28(4):337-43. Available from: http://www.scielo.br/pdf/ ape/v28n4/1982-0194-ape-28-04-0337.pdf 